\title{
The construction of gender and sexuality in the approach of key international law actors to the circumcision of children
}

\section{Introductory Comments}

This paper examines a perplexing question concerning the approach of key actors within the international community - specifically the World Health Organisation (WHO), as found in a number of documents co-authored with various bodies of the United Nations (UN); and the Committee on the Rights of the Child (CRC), in a recent Recommendation issued jointly with the Committee on the Elimination of Discrimination Against Women (CEDAW) - towards the circumcision of children. Given that the circumcision of both girls and boys involves the prima facie harm of removing healthy bodily tissue for non-therapeutic, adult-oriented reasons, how has the situation become so polarised, with the circumcision of girls universally condemned, ${ }^{1}$ and indeed officially designated as 'mutilation', whereas the circumcision of boys is not merely universally condoned, but also encouraged and facilitated? Why do we have a concept of 'female genital mutilation' (FGM) but not one of 'male genital mutilation' (MGM)?

The question is hardly novel. There is a long-standing, broad, and expanding body of academic and medical professional literature which argues that, if FGM is seen as breaching the rights of the girl child, then MGM should similarly be seen as breaching the rights of the boy child. As I will argue below, the substantive claims made in this literature deserve serious consideration, and in some jurisdictions they have indeed been influential. But internationally they have, by and large, fallen on deaf ears. The approach of the international community has not been to defend the practice of MGM, but to neglect it, and treat it as a non-issue in human rights terms. Essentially, the circumcision of boys is not seen to cause harm; or at least, any harm caused is not of such magnitude as to constitute a violation of the rights of the child. In stark contrast, FGM is seen as inherently harmful and discriminatory, and in breach of various rights of the girl child, including the right to freedom from torture and inhuman or degrading treatment; the right to physical integrity; and the right to health. WHO and co-authors explain that the term 'FGM' was adopted in part to underscore 'the gravity and harm of the act' and partly because the term 'female circumcision' wrongly 'draws a parallel with male circumcision and, as a result, creates confusion between these two distinct practices'. ${ }^{2}$

In this paper I argue that one important factor explaining this polarisation of approach towards circumcision in girls and boys is the inadequacy of the models of gender and sexuality which underpin the discourses around circumcision generated by WHO and UN co-

\footnotetext{
${ }^{1}$ WHO, OHCHR, UNAIDS, UNDP, UNECA, UNESCO, UNFPA, UNHCR, UNICEF, UNIFEM, Eliminating female genital mutilation: an interagency statement (Geneva: WHO, 2008) http://www.who.int/reproductivehealth/publications/fgm/en/index.html.

${ }^{2}$ WHO et al, (2008), n 1 above, 22. More recently, for tactical and diplomatic reasons, the more neutral term 'genital cutting' is used instead or as well as the term FGM: see for example UNFPA and UNICEF Voices of Change: 2014 Annual Report of the UNFPA-UNICEF Joint Programme on Female Genital Mutilation/Cutting: Accelerating Change (New York: UNFPA and UNICEF, 2015).
} 
authors, and by the CRC. As will be seen, these discourses utilise a simple binary model of gender, in which, for the purposes of identifying and analysing breaches of the rights of the child, the interrelation of power with gender is understood solely in terms of patriarchal domination: gender is a source of empowerment for males and a source of disempowerment for females. The understanding of the relation between sexuality and circumcision is that it is a subset of discourses around gender, and is similarly structured in binary terms: FGM, which is seen as the theft of female sexuality, is one mechanism through which gender domination is expressed. MGM, on the other hand, is not seen to impinge on male sexuality and so does not raise issues of gender domination or the appropriation of sexuality. Of course, there are many more strands to debates around both FGM and MGM, to do with notions of 'harm' and 'benefit' and the extent of each; best interests; parental rights; religious freedom; cultural expression; identity formation and consolidation; and other issues besides. My focus, however, will be on exploring this differential approach in terms of the construction of gender and sexuality, and its implications for the rights of the child, particularly the boy child.

The argument proceeds as follows. First, in section 2, I will consider the range of practices understood to comprise circumcision in both girls and boys. Then, in section 3, I will lay out some key statements made by WHO and UN co-authors, and the CRC working together with CEDAW, regarding both policy development and implementation, to demonstrate that the differential approach to circumcision in girls and boys which these actors take is not merely one of policy, but of discourse: for all these actors, FGM is constructed primarily as a rights issue, whereas MGM is constructed primarily as a health issue or an issue of religious freedom. Then, in section 4, I shall briefly consider some of the arguments against this approach that have been made by academic and medical professional commentators, and some assessment of their impact will be undertaken. In the fifth and sixth sections of the paper, I will consider the defensibility of the constructions of gender and sexuality respectively which underpin the discourse found in various documents produced by these key international actors, and seek to demonstrate the paucity of this discourse in terms of being able to identify clear and present breaches of the rights of the boy child.

\section{Practices of Circumcision}

FGM is an umbrella term which applies to a range of practices, involving different actors in different contexts. According to a recent United Nations Population Fund (UNFPA) report 'Although primarily concentrated in 29 countries in Africa and the Middle East, FGM is a universal problem. It is practiced in some countries in Asia, including India, Indonesia, Iraq and Pakistan, as well as in Latin America, and among immigrant populations in Western Europe, North America, Australia and New Zealand'. ${ }^{3}$ WHO has identified four types of FGM ${ }^{4}$ within which the myriad variants of the practice can be classified. The most recent wording currently available is that used by WHO in $2016,{ }^{5}$ which is repeated here in full:

\footnotetext{
${ }^{3}$ M. Liang, E. Loaiza, N. J. Diop and B. Legesse, Demographic Perspectives on Female Genital Mutilation (New York: UNFPA, 2015), 7, footnote omitted.

${ }^{4}$ WHO et al, (2008), n 1 above, 4.

${ }^{5}$ WHO, Female Genital Mutilation Factsheet (Geneva: WHO, 2016), http://www.who.int/mediacentre/factsheets/fs241/en/.
} 
Type 1: Often referred to as clitoridectomy, this is the partial or total removal of the clitoris (a small, sensitive and erectile part of the female genitals), and in very rare cases, only the prepuce (the fold of skin surrounding the clitoris).

Type 2: Often referred to as excision, this is the partial or total removal of the clitoris and the labia minora (the inner folds of the vulva), with or without excision of the labia majora (the outer folds of skin of the vulva).

Type 3: Often referred to as infibulation, this is the narrowing of the vaginal opening through the creation of a covering seal. The seal is formed by cutting and repositioning the labia minora, or labia majora, sometimes through stitching, with or without removal of the clitoris (clitoridectomy).

Type 4: This includes all other harmful procedures to the female genitalia for nonmedical purposes, e.g. pricking, piercing, incising, scraping and cauterizing the genital area.

MGM has a much wider and more diverse global profile than FGM, being part of the normative culture for much of the USA and other 'developed' states as it is in many areas of Africa and Asia, and is much more commonly performed. Recent, authoritative data in respect of prevalence is not available. In 2007 WHO estimated that $30 \%$ of the global male adult population is circumcised, $68 \%$ of whom are Muslim and $0.8 \%$ of whom are Jewish, whilst what is described as 'non-religious circumcision' undertaken in the United States comprised $12.8 \%$, and elsewhere, principally but not only in a number of African countries, $17.6 \%$, of the global total. ${ }^{6}$ There is evidence that rates in the United States and other developed countries are in decline, ${ }^{7}$ and in most of Europe circumcision for non-religious reasons is now rare, having been common in the middle of the $20^{\text {th }}$ century.

There is no WHO typology of MGM comparable to the above schema of types of FGM. The most common form of male circumcision involves the removal of the prepuce - the foreskin around the head of the penis - although there is great variation in terms of clinical methods used $^{8}$ and in the amount of flesh removed, particularly in religious and traditional circumcisions carried out by non-medical professionals. ${ }^{9}$ Van den Brink and Tigchellaar have suggested that MGM can be understood as either African, American, or Abrahamic. In the first case MGM is commonly carried out on adolescent boys by non-professional circumcisers as part of a rite of passage from childhood into adulthood; the second typically involves neonatal circumcision by medical professionals; the third encompasses circumcision justified by religious discourse, is typically neonatal in a Jewish context or performed on older boys in an Islamic context, and most often but not always performed by a religious circumciser. ${ }^{10}$

\footnotetext{
${ }^{6}$ WHO and Joint United Nations Programme on HIV/AIDS (UNAIDS), Male circumcision: global trends and determinants of prevalence, safety and acceptability (Geneva: WHO, 2007) http://www.who.int/reproductivehealth/publications/rtis/9789241596169/en/, 8, table 2.

${ }^{7}$ M. Owings, S. Uddin and S. Williams, 'Trends in Circumcision for Male Newborns in U.S. Hospitals: 19792010' (2013), available on line only at https://www.cdc.gov/nchs/data/hestat/circumcision_2013/circumcision_2013.pdf.

${ }^{8}$ See WHO and UNAIDS, (2007), n 6 above, 16-17.

${ }^{9}$ WHO and UNAIDS, (2007), n 6 above, 19-20.

${ }^{10}$ M. Van den Brink and J. Tigchellaar, 'Shaping Genitals, Shaping Perceptions: A Frame Analysis of Male and Female Circumcision’ (2012) 30(4) Netherlands Quarterly of Human Rights 417-445, 429.
} 
The WHO report also gives brief mention to 'The rite of skin-stripping, whereby much of the skin of the penile shaft is progressively flayed, [which] is used to prove bravery, and therefore marriage suitability, among various ethnic groups'. ${ }^{11}$ Debra DeLaet provides a little more detail on a variant which 'involves peeling the skin of the entire penis, sometimes including the skin of the scrotum and pubis. This form was practiced historically among some tribes in South Arabia and, according to one scholar of Arab and Islamic Law who studies the issue, may still be practiced today'. ${ }^{12}$ Kirsten Bell ${ }^{13}$ cites the description of subincision in Australia provided by the anthropologist Ashley Montagu, ${ }^{14}$ which involves:

slitting open the whole or part of the penile urethra along the ventral or under surface of the penis. The initial cut is generally about an inch long, but this may subsequently be enlarged so that the incision extends from the glans to the root of the scrotum, in this way the whole of the under part of the penile urethra is laid open.

Earp discusses Muslim circumcision in Pakistan, in which the boy, typically aged between three and seven 'is held in a seated position, with both legs apart.... a probe, a cutter made of wood, and a razor are used [to excise] the prepuce' following which 'ashes of burnt wood are [applied] to establish haemostasis'. Typically, anaesthetic or sutures are not used. Instruments are not usually sterilized. ${ }^{15}$

As can be seen, the variety of practices, in terms of invasiveness, that come under the umbrella term FGM are mirrored to some extent by those which come under the umbrella of male circumcision or MGM. Van den Brink and Tigchellaar have suggested that circumcision involving removal of the prepuce of the penis is comparable to the most common form of FGM "called "sunna" which involves the removal of the prepuce of the clitoris', ${ }^{16}$ and it seems arguable that the worst forms of MGM are, whether or not comparable to the worst forms of FGM, clearly more invasive than the mildest, type 4, variants of FGM. ${ }^{17}$ Whilst it is to be expected that other factors, such as prevalence of particular, especially severe, types of FGM or MGM, will have some effect on determining the approach of key international actors, and rightly so in a world of finite resources, nonetheless one would expect that these actors would treat broadly similar breaches in a broadly similar way, including with regard to the labelling of such as human rights violations, irrespective of the gender of the child. But as will now be discussed, whilst the international community seeks to abolish all FGM, the most that the boy child can hope for is that his MGM will be carried out in a medicalised and hygienic environment.

\footnotetext{
${ }^{11}$ WHO and UNAIDS, (2007), n 6 above, 21.

12 D. L. DeLaet, 'Framing Male Circumcision as a Human Rights Issue? Contributions to the Debate Over the Universality of Human Rights' (2009) 8(4) Journal of Human Rights 405-426, 412, citing S. A. Abu-Sahlieh Male and Female Circumcision Among Jews, Christians and Muslims: Religious, Medical, Social and Legal Debate (Warren Center, PA: Shangri La Publications, 2001), 9.

${ }^{13}$ K. Bell, 'Genital Cutting and Western Discourses on Sexuality' (2005) 19(2) Medical Anthropology Quarterly 125-148, 126.

${ }^{14}$ A. Montagu, Coming into Being among the Australian Aborigines: The Procreative Beliefs of the Australian Aborigines (London: Routledge and Kegan Paul, 2nd ed, 1974), 312.

${ }^{15}$ B. D. Earp, 'Female genital mutilation and male circumcision: toward an autonomy-based ethical framework' (2015) 5 Medicolegal and Bioethics 89-104, 93, citing S.A. Rizvi, S. Naqvi, M. Hussain and A. Hasan, 'Religious circumcision: a Muslim view' (1999) 83(S1) BJU International 13-16.

${ }^{16}$ Van den Brink and Jet Tigchellaar, n 10 above, 424.

${ }^{17}$ An observation made by Sir Stephen Munby P in Re B and G (children) (No 2); Leeds City Council v M and others [2015] All ER (D) 99 (Jan), para. 63.
} 


\section{The position of the international community on the circumcision of children}

The most immediately relevant international law, Art 24(3) of the United Nations Convention on the Rights of the Child (UNCRC), which given the near-universal ratification of that Convention, can be taken to represent a global consensus on the propriety of the circumcision of children, is phrased in gender-neutral terms. Art 24(3) provides that 'States Parties shall take all effective and appropriate measures with a view to abolishing traditional practices prejudicial to the health of children'. Although it was ultimately determined that Art 24(3) should not mention FGM explicitly, unlike other international law instruments, ${ }^{18}$ there has never been any doubt that this was the main focus of Art 24(3), just as it had been for the Working Group responsible for drafting the CRC, ${ }^{19}$ utilising the definition of 'traditional practices' developed by an earlier Working Group, which focussed to a very great extent on FGM. ${ }^{20}$ Male circumcision, by contrast, was not discussed at all by the Working Group. The assumptions underpinning this differential approach, involving slippage from gender-neutral terminology into gendered policy and practice, itself articulating a model of gender and power as unidirectional and under which only girls, and not boys, can be victims - set the pattern for subsequent discourse around the topic of the circumcision of children.

This pattern was not immediately apparent because the first post-UNCRC intervention, made in February 1990, before that Convention came into force, ${ }^{21}$ came from CEDAW. ${ }^{22}$ CEDAW called for the eradication of FGM. Given the mission of CEDAW, it would have been inappropriate to draw any general conclusions from the absence of any consideration of the circumcision of boys by the Committee. But when WHO together with The United Nations Children's Fund (UNICEF) and the UNFPA published a joint statement on FGM in $1997,{ }^{23}$ it was clear by omission that MGM was not on the international human, or children's, rights agenda. That joint statement was updated in 2008 with an increased number of UN coauthors. ${ }^{24}$ According to the 2008 statement, FGM offers no health benefits, and carries many health risks, for a girl subjected to it, and neither are there any public health benefits, with 'no research evidence to suggest that such procedures could reduce the risk of HIV

\footnotetext{
${ }^{18}$ See for example Art 5, Protocol to the African Charter on Human and Peoples' Rights on the Rights of Women in Africa, (the 'Maputo Protocol') adopted 11 June 2003, http://www.achpr.org/instruments/womenprotocol/\#5.

${ }^{19}$ See UN Doc. E/CN.4/1987/25, para. 35; UN Doc. E/CN.4/1987/25, para. 38; UN Doc. E/CN.4/1986/42); J. Smith (1998) 'Male Circumcision and the Rights of the Child' in M. Butlerman, A. Hendriks and J. Smith (eds) To Baehr in Our Minds: Essays in Human Rights from the Heart of the Netherlands (SIM Special No. 21) (Netherlands Institute of Human Rights (SIM), University of Utrecht, Netherlands, 1998) 465-498.

${ }^{20}$ H. E. Warzazi, Report of the Working Group on Traditional Practices Affecting the Health of Women and Children [unpublished] 1986 Feb 4. Prepared for United Nations Commission on Human Rights, Forty-second session, 3 February - 14 March 1986. Item 19 of the provisional agenda. (E/CN.4/1986/42).

${ }^{21}$ The UNCRC was opened for signature by General Assembly Resolution 44/25 on 20 November 1989 and came into force on 2 September 1990.

${ }^{22}$ The Committee on the Elimination of Discrimination against Women (1990) General Recommendation 14: Female Circumcision, 2 Feb 1990, http://www.un.org/womenwatch/daw/cedaw/recommendations/recomm.htm. See also Human Rights Committee (2000) General Comment No. 28 on the Equality of Rights between Men and Women, UN Doc. CCPR/C/21/Rev.1/Add.10, para. 11; Committee Against Torture (2007) General Comment on the Implementation of Article 2 by State Parties UN Doc. CAT/C/GC/2, para. 18.

${ }^{23}$ WHO, UNICEF and UNFPA, Female Genital Mutilation: A joint WHO/UNICEF/UNFPA Statement (Geneva: WHO, 1997).

${ }^{24}$ WHO et al, (2008), n 1 above.
} 
transmission'. ${ }^{25}$ The statement aimed to facilitate the complete elimination of FGM 'within one generation'. ${ }^{26}$

In 2010, WHO, again working together with a large number of UN, and now also NGO, partners, published its global strategy to prevent the medicalisation of FGM. ${ }^{27}$ Although a policy of medicalisation had been pursued in earlier decades, it was abandoned because it was 'too successful, resulting in continued practice instead of gradual decline'. ${ }^{28}$ The 2010 approach rejects harm-reduction options, instead preferring to reinforce the zero-tolerance approach and the aim of eradication. ${ }^{29}$ This approach was justified not merely on health grounds, but also because FGM is 'an extreme form of discrimination against women', ${ }^{30}$ and 'universally unacceptable, as it is an infringement of the physical and psychosexual integrity of women and girls and is a form of violence against them'. ${ }^{31}$ This policy applies to all of the four types of FGM identified by WHO and partners. ${ }^{32}$

WHO policy on male circumcision is very different from this. This was articulated by WHO in reporting the findings of its global survey of male circumcision, published in $2007 .{ }^{33}$ The document opens with the observation that 'Male circumcision is one of the oldest ${ }^{34}$ and most common surgical procedures worldwide', 35 before proceeding to note its religious significance particularly to Jews and Muslims, ${ }^{36}$ and its status as a standard procedure in the USA, Canada, New Zealand and other developed states. ${ }^{37}$ FGM is similarly culturally embedded, but for WHO this is only a superficial point of similarity:

While both male circumcision and female genital mutilation (FGM) are steeped in culture and tradition, the health consequences of each are drastically different. Male circumcision may seem similar as far as definition is concerned - "partial ... removal of the external genitalia" - but in practice is substantially different. FGM, also referred to as "female circumcision", comprises surgical procedures involving partial or total removal of the external female genitalia. It is the manifestation of deep-rooted gender inequality that assigns women an inferior position in societies, and is

\footnotetext{
${ }^{25}$ WHO et al, (2008), n 1 above, 27-28.

${ }^{26}$ WHO et al, (2008), n 1 above, 3, 21.

${ }^{27}$ WHO (2010) Global strategy to stop health-care providers from performing female genital mutilation. Coauthors included UNFPA, UNHCR, UNICEF, UNIFEM, WHO, FIGO, ICN, MWIA, WCPA, WMA.

${ }^{28}$ Van den Brink and Tigchellaar (2012), n 10 above, 428.

${ }^{29}$ Most recently, In May 2016, WHO published WHO guidelines on the management of health complications from female genital mutilation (Geneva: WHO, 2016a) available at

http://www.who.int/reproductivehealth/topics/fgm/management-health-complications-fgm/en/.

${ }^{30}$ WHO et al, (2008), n 1 above, 1.

${ }^{31}$ WHO and UNAIDS, (2007), n 6 above, 27-28.

${ }^{32}$ WHO et al, (2008), n 1 above, 4; WHO (2016), n 5 above.

${ }^{33}$ WHO and UNAIDS, (2007), n 6 above. It is notable that the UN partners which are involved in the FGM campaign are absent here, replaced by the public health body, UNAIDS. See also WHO and UNAIDS (2010) Neonatal and child male circumcision: a global review (Geneva: WHO, 2010).

${ }^{34}$ See, for example, J. C. Angulo and M. Garcia-Diez, 'Male Genital Representation in Paleolithic Art: Erection and Circumcision Before History’ (2009) 74(1) Urology 10-14; D. C. Kalcher and K. G. Swan 'A Cut Above: Circumcision as an Ancient Status Symbol' (2010) 76(1) Urology 18-20.

${ }^{35}$ WHO and UNAIDS, (2007), n 6 above, 1, 3.

${ }^{36}$ WHO and UNAIDS, (2007), n 6 above, 3-4.

${ }^{37}$ WHO and UNAIDS, (2007), n 6 above, 7.
} 
unambiguously linked to a reduction in women's sexual desire and an irreversible loss of capability for a type of sexual functioning that many women value highly. ${ }^{38}$

The clear implication is that these factors have no relevance to MGM. Furthermore, although noting that any health benefits of MGM have long been disputed, WHO pointed out that by 2007, 'there is now conclusive evidence that male circumcision significantly reduces risk of HIV infection in men'. ${ }^{39}$ The view of WHO is that the health benefits of MGM are not confined to the prevention of HIV infection: 'Epidemiological studies have shown circumcised men have a lower risk of several reproductive tract infections than uncircumcised men'. ${ }^{40}$ As for the intervention itself, circumcision of neonates is seen as 'a relatively simple, quick and safe procedure when performed in a clinical setting under aseptic conditions by trained professionals. Complication rates are between 1 in 500 and 2 in 100 and are usually minor'. ${ }^{41}$ And although 'Adolescent or adult circumcision in clinical settings can cause bleeding, haematoma or sepsis' there are 'no long-term sequelae when undertaken in a clinical setting by experienced, well trained providers'. ${ }^{42}$

However, after having reviewed the evidence, WHO concluded that 'Male circumcision is medically indicated for only a few conditions. There is substantial evidence that circumcised men have a lower risk of some reproductive tract infections, as well as penile cancer, but some of these conditions are rare $^{43}$ while others are uncommon or treatable, and routine neonatal circumcision is not currently recommended on medical grounds'. ${ }^{4}$ On the other hand, WHO does not actively oppose circumcision carried out on health or other grounds. Its main concern is that MGM should be performed in safe and hygienic facilities. ${ }^{45}$ The 2007 document does express concern about 'circumcisions undertaken in unhygienic conditions, by inexperienced providers with inadequate instruments, or with poor after-care, [which] can result in serious complications and even death. ${ }^{46}$ As such, although not positively recommending MGM, WHO's policy is to accept and seek to medicalise the practice.

Absent from WHO discourse on male circumcision is any concern about the rights of the boy child. WHO's 2007 document on MGM, although having a final section headed 'human rights, legal and ethical implications', ${ }^{47}$ and whilst noting that the term 'female genital mutilation' is used as this 'reinforces that this practice is a violation of girls' and women's human rights', ${ }^{48}$ has nothing to say about the human rights of boy children who experience MGM, merely noting that 'Any future expansion of male circumcision services needs to be considered within a legal, regulatory and policy framework to ensure accessibility,

\footnotetext{
${ }^{38}$ WHO and UNAIDS, (2007), n 6 above, 27.

${ }^{39}$ WHO and UNAIDS, (2007), n 6 above, 29.

${ }^{40}$ WHO and UNAIDS, (2007), n 6 above, 13.

${ }^{41}$ WHO and UNAIDS, (2007), n 6 above, 18.

${ }^{42}$ WHO and UNAIDS, (2007), n 6 above, 21.

${ }^{43}$ One study found that more than 300,000 boys would need to be circumcised to prevent one case of penile cancer, and that 644 of those circumcised would develop complications. See American Academy of Family Physicians (2007) Circumcision: Position Paper on Neonatal Circumcision http://www.cirp.org/library/statements/aafp2002/.

${ }^{44}$ WHO and UNAIDS, (2007), n 6 above, para. 2.6.

${ }^{45}$ See the discussion at WHO and UNAIDS, (2007), n 6 above, 16-21.

${ }^{46}$ WHO and UNAIDS, (2007), n 6 above, 21.

${ }^{47}$ WHO and UNAIDS, (2007), n 6 above, 28.

${ }^{48}$ WHO and UNAIDS, (2007), n 6 above, 27, fn. 4. See also WHO, Sexual health, human rights and the law (Geneva: WHO, 2015), which follows the same pattern.
} 
acceptability and quality of service provision' ${ }^{49}$ Such future expansion was proposed in the document, WHO and co-authors noting that 'So far, it is the only new prevention method to have shown consistent efficacy through randomized controlled trials, ${ }^{50}$ and promised to be 'highly cost-effective intervention' 51 for reduction in the spread of HIV, which is seen to enhance the rights to life and health of both the individual boy and others in their community. ${ }^{52}$

In subsequent years, a WHO-led campaign to encourage the voluntary medical circumcision of men and boys (VMMC) in eastern and southern Africa as a key strategy to reduce the spread of HIV has gathered pace, ${ }^{53}$ with 11 million young men and adolescent boys circumcised between 2008 and $2016 .{ }^{54}$ In 2016 new targets were set, to have $90 \%$ of boys and men aged 10-29 circumcised by $2021 .{ }^{55}$ The rationale for encouraging the circumcision of boys aged 15 or older is that at least a proportion will be sexually active, ${ }^{56}$ and the rationale for including 10-14 year-olds in the programme is that it is 'mainly an investment in the (not-too-distant) future' ${ }^{57}$ Moreover, it is envisaged that 'Early infant male circumcision is likely to become more acceptable and in-demand over time', ${ }^{58}$ so that in future the programme should be extended to younger boys. As can be seen, the difference in approach of WHO and UN partners in respect of MGM could not be more different from the approach of WHO and UN partners in respect of FGM. ${ }^{59}$

The most recent articulation of discourse around traditional harmful practices comes from the CEDAW and the CRC, in the form of a joint General Recommendation on harmful practices. ${ }^{60}$ The Recommendation calls for a 'holistic strategy' to combat four harmful

\footnotetext{
${ }^{49}$ WHO and UNAIDS, (2007), n 6 above, 28.

${ }^{50}$ WHO and UNAIDS, (2007), n 6 above, 28.

${ }^{51}$ WHO and UNAIDS, (2007), n 6 above, 27.

${ }^{52}$ WHO and UNAIDS A Framework For Voluntary Medical Male Circumcision: Effective HIV Prevention And A Gateway To Improved Adolescent Boys' and Men's Health in Eastern and Southern Africa By 2021, (Geneva: WHO, 2016b), 2, http://apps.who.int/iris/bitstream/10665/246234/1/WHO-HIV-2016.17-eng.pdf?ua=1

${ }^{53} \mathrm{WHO}$, Joint strategic action framework to accelerate the scale-up of voluntary medical male circumcision for HIV prevention in eastern and southern Africa, 2012-2016 (Geneva: WHO,2011)

http://files.unaids.org/en/media/unaids/contentassets/documents/unaidspublication/2011/JC2251_Action_Frame work_circumcision_en.pdf

${ }^{54}$ For critical discussion, see K. Bell, 'HIV prevention: Making male circumcision the 'right' tool for the job' (2015) 10(5-6) Global Public Health 552-572; M. Fox and M. Thomson, 'The new politics of male circumcision: HIV/AIDS, health law and social justice' (2012) 32(2) Legal Studies 255-281.

${ }^{55}$ WHO and UNAIDS (2016a), n 61 above, 2.

${ }^{56}$ WHO and UNAIDS (2016a), n 61 above, 8, para 5.1.

${ }^{57}$ WHO and UNAIDS (2016a), n 61 above, 8, para 5.1.

${ }^{58}$ WHO and UNAIDS (2016a), n 61 above, 8, para 5.1.

${ }^{59}$ For reasons of space, I do not consider here the UN's own output on FGM or MGM. It is very similar to the approach taken in tandem with WHO. See Secretary-General of the UN, Ending female genital mutilation:

Report of the Secretary-General (2012) http://www.un.org/ga/search/view_doc.asp?symbol=E/CN.6/2012/8; UNGA Resolution A/RES/67/146 of 12 December 2012

http://www.un.org/en/ga/search/view_doc.asp?symbol=A/RES/67/146, preamble and para. 4; UNGA Resolution A/RES/69/150 of 18 December 2014, http://www.un.org/en/ga/search/view doc.asp?symbol=A/RES/69/150; Human Rights Council Resolution A/HRC/RES/27/22 https://documents-ddsny.un.org/doc/UNDOC/GEN/G14/176/97/PDF/G1417697.pdf?OpenElement; Goal 5.3, Sustainable Development Goals.

${ }^{60}$ The Committee on the Elimination of Discrimination against Women and the Committee on the Rights of the Child, Joint general recommendation No. 31 of the Committee on the Elimination of Discrimination against Women/general comment No. 18 of the Committee on the Rights of the Child on harmful practices, CEDAW/C/GC/31-CRC/C/GC/18 14 ${ }^{\text {th }}$ November 2014 (New York: UN, 2014) available from
} 
practices: child or forced marriage, polygamy, and honour-crimes, as well as FGM. As is made clear in the introduction to this document, its focus is on 'those practices affecting women and children, primarily girls'. ${ }^{61}$ It is acknowledged that 'the Committees recognize that boys are also the victims of violence, harmful practices and bias and that their rights must be addressed'. ${ }^{62}$ However, the (absolutely warranted) focus on $\mathrm{FGM}^{63}$ is accompanied by a total absence of any discussion of MGM. Indeed, the only specific mention of boys in the main body of the Recommendation is in that part of the discussion concerned with developing a holistic approach, which highlights the need to facilitate the empowerment of women and girls. State parties are exhorted to 'Engage men and boys in creating an enabling environment that supports the empowerment of women and girls' ${ }^{64}$ In an earlier paragraph it is recognised that both girls and boys require assistance and support 'to change gender-based attitudes and adopt more positive roles and forms of behaviour ${ }^{\prime 65}$ but the best reading of this, given the subsequent wording of the Recommendation, is that boys are seen as needing assistance to avoid developing into sexist or patriarchal adults males.

The absence of any discussion of MGM is explicable by reference to the theory of gender, sexuality and power which underpins the Recommendation. In the chapter of the Recommendation articulating the rationale for its creation, it is explained that 'harmful practices are deeply rooted in social attitudes according to which women and girls are regarded as inferior to men and boys based on stereotyped roles' ${ }^{66}$ Harmful practices 'are all strongly connected to and reinforce socially constructed gender roles and systems of patriarchal power relations' ${ }^{67}$ In the chapter concerned with the causes of harmful practices it is explained that 'The causes of harmful practices are multidimensional and include stereotyped sex- and gender-based roles, the presumed superiority or inferiority of either of the sexes, attempts to exert control over the bodies and sexuality of women and girls, social inequalities and the prevalence of male-dominated power structures'. ${ }^{68} \mathrm{In}$ similar vein, the attraction of FGM for those who practice and advocate it is that it provides 'an effective method of control of the sexuality of women and girls' ${ }^{69}$ Although it is perfectly legitimate for CEDAW to pursue its particular mandate to focus on the situation of women and girls, the mandate of the CRC is to give guidance on the relevant international law - here, Art 24(3) of the UNCRC - as it applies to all children, and it is disappointing that the reader of this Recommendation may well be left with the impression that questions about gender and power are not relevant to an understanding of MGM.

http://www.ohchr.org/EN/HRBodies/CEDAW/Pages/Recommendations.aspx. Para. 5 of this general recommendation updates that issued by CEDAW in 1990 (above). Although the Convention Committees are not formally generators of policy, their main roles being to interpret international law standards and monitor the operation of relevant Convention, the Recommendations which the Committees issue do contain more or less prescriptive statement which comprise something very similar to a 'policy'.

${ }^{61}$ CEDAW and CRC (2014), n 60 above, para 1.

${ }^{62}$ CEDAW and CRC (2014), n 60 above, para. 4.

${ }^{63}$ CEDAW and CRC (2014), n 60 above, para. 19, defines FGM and gives an overview of the practice and the various harms caused.

${ }^{64}$ CEDAW and CRC (2014), n 60 above, para. 69, recommendation (f).

${ }^{65}$ CEDAW and CRC (2014), n 60 above, para. 67.

${ }^{66}$ CEDAW and CRC (2014), n 60 above, para. 6.

${ }^{67}$ CEDAW and CRC (2014), n 60 above, para. 9.

${ }^{68}$ CEDAW and CRC (2014), n 60 above, para. 17.

${ }^{69}$ CEDAW and CRC (2014), n 60 above, para. 19. 
The Recommendation does on occasion acknowledge that part of the explanation for the continuance of harmful practices is discrimination on the basis of age, ${ }^{70}$ but these references are not developed into specific policy or practice recommendations and cannot really be seen as any more than tokenistic. This Recommendation positions itself in the context of other CEDAW Recommendations and CRC Comments relevant to harmful practices, including those published by the CRC concerning protection from corporal punishment ${ }^{71}$ and freedom from all forms of violence. ${ }^{72}$ In contrast to FGM, the interests of the boy child in bodily integrity are collapsed into these other, non-sexualised harms. By the combination of these various factors, the consequence is that the circumcision of boy children is an issue placed firmly beyond the agenda of the joint Recommendation.

\section{Challenges to the approach of the international community}

The policies and activities of the international actors discussed in the previous section of this paper are based on the premise that MGM is lawful. This premise has not, however, gone unchallenged. There is a body of literature, which has accumulated over a number of decades, which argues against the approach of WHO, UN bodies and the Convention Committees. In this section I summarise the key elements of those arguments. Not surprisingly, given the hegemony of the view that MGM is lawful, counter-arguments are normative, rather than descriptive. As Swatek-Evenstein notes, 'If children's rights are indeed seriously impaired by allowing ritual male circumcision... the way forward is not to claim that the practice is illegal, only that it should be illegal'. ${ }^{73}$ Nonetheless, the arguments which are made do fit comfortably within accepted legal concepts, principles, and definitions. The debates traverse a number of fields, but most arguments are structured around discourses of health or of rights. There are interrelated debates and disputes around the claimed health risks and benefits of MGM, but as the WHO position is that any health benefits are marginal and do not justify routine circumcision on preventative grounds - a view also held by many professional bodies around the world, ${ }^{74}$ (although with the notable exception of bodies in the United States) ${ }^{75}$ -

\footnotetext{
${ }^{70}$ See for example CEDAW and CRC (2014), n 60 above, paras. 6 ('discrimination based on sex, gender and age, amongst other things'); para. 15 (discrimination on the basis of, among other things, sex, gender and age, in addition to multiple and/or intersecting forms of discrimination').

${ }^{71}$ Committee on the Rights of the Child (2007) General Comment No. 8 (2006) The right of the child to protection from corporal punishment and other cruel or degrading forms of punishment (arts. 19; 28, para. 2; and 37, inter alia) CRC/C/GC/8, 2 March 2007 (New York: UN, 2007).

${ }^{72}$ Committee on the Rights of the Child (2011) General comment No. 13 (2011) The right of the child to freedom from all forms of violence CRC/C/GC/13, 18 April 2011 (New York: UN, 2011).

${ }^{73}$ M. Swatek-Evenstein, 'Limits of Enlightenment and the Law - On the Legality of Ritual Male Circumcision in Europe today' (2013) 29(77) Merkourios 42-50, 50.

${ }^{74}$ See for example BMA, The law and ethics of male circumcision: guidance for doctors (London: BMA, 2007); Royal Australian College of Physicians, Circumcision of infant males (policy statement) (Sydney: RACP, 2010); College of Physicians and Surgeons of British Columbia, Circumcision: infant male (policy statement) (Vancouver: CPSBC, 2009); Central Union for Child Welfare, Position statement on the circumcision of boys (Helskinki: CUCW, 2003); Koninklijke Nederlandsche Maatschappij tot bevordering der Geneeskunst (KNMG), KNMG Viewpoint Non-therapeutic circumcision of male minors (Utrecht: KNMG, 2010) https://www.knmg.nl/circumcision/; Joint Statement of Nordic Ombudswoman for Children and counterparts in Denmark, Finland, Greenland, Iceland and Sweden (2013) https://www.crin.org/en/library/news-archive/malecircumcision-nordic-ombudspersons-seek-ban-non-therapeutic-male.

${ }^{75}$ American Academy of Pediatrics, 'Circumcision Policy Statement' (2012) 103(3) Pediatrics, 686, http://pediatrics.aappublications.org/content/pediatrics/130/3/585.full.pdf); US Federal Center for Disease Control (CDC (2014) Male Circumcision

https://www.cdc.gov/hiv/pdf/prevention_research_malecircumcision.pdf; see M. Frisch and B.D. Earp, 'Circumcision of male infants and children as a public health measure in developed countries: A critical
} 
health-based arguments will not be considered here. Instead, I will focus on the legal arguments.

\subsection{Human rights-based arguments}

One set of arguments is grounded in the text of the UNCRC. Price for example has argued that the way in which the international community has interpreted Art 24(3) is problematic. ${ }^{76}$ Article 31 of the Vienna Convention on the Law of Treaties requires that the ordinary meaning be given to the words of the treaty in their context and in the light of its object and purpose'. Recourse can only be made to documents such as traveaux préparatoires if the application of Article 31 leaves the meaning of the provision on question ambiguous, or produces an unreasonable or absurd result. ${ }^{77}$ As MGM fits the requirement of a 'traditional practice', and as it involves actual bodily harm and may engender further health problems, and is not medically indicated or recommended as a routine intervention, it is therefore prejudicial to the health of the boy child and so within the scope of Art. 24(3). State parties to the UNCRC have signed up to the abolition of harmful practices and should honour that legal commitment. Other arguments are grounded around other articles of the UNCRC. Smith for example has argued that Arts. $19(1)^{78}$ and $37(a)^{79}$ also prohibit MGM. ${ }^{80}$ Boyle and colleagues, ${ }^{81}$ Svobola, ${ }^{82}$ and Adler, ${ }^{83}$ also identify those Articles, and Adler ${ }^{84}$ adds arguments concerning the relevance of Arts. $6^{85}, 34^{86}$ and $36 .^{87}$

Turning to Art. 3(1), although this particular formulation of the best interests standard is relatively weak, ${ }^{88}$ it nonetheless requires a consideration of the best interests of the particular boy child; and given that MGM constitutes a bodily invasion and the removal of healthy tissue with lasting consequences, and is neither risk- nor pain-free, then in a non-therapeutic

assessment of the evidence' (2016) Global Public Health 1-16; Pubmed Record DOI:

10.1080/17441692.2016.1184292; J.S. Svoboda and R.S. Van Howe 'Out of step: fatal flaws in the latest AAP policy report on neonatal circumcision' (2013) J Med Ethics 434-441; P. W. Adler, 'The Draft CDC

Circumcision Recommendations: Medical, Ethical, Legal and Procedural concerns' (2016) 24 International Journal of Children's Rights 239-264; B. E. Rivin, D. S. Diekema, A. C. Mastroianni, J. N. Krieger, J. D.

Klausner and B. J. Morris, 'Critical Evaluation of Adler's Challenge to the CDC's Male Circumcision

Recommendations' (2016) 24 International Journal of Children's Rights 265-303.

${ }^{76}$ C. Price, 'Male Circumcision: An Ethical and Legal Affront' (1997) 128 Bulletin of Medical Ethics 13-19.

77 Art. 32, Vienna Convention on the Law of Treaties.

${ }^{78}$ This requires state parties to 'take all appropriate legislative, administrative, social and educational measures to protect the child from all forms of physical or mental violence, injury or abuse, neglect or negligent treatment, maltreatment or exploitation, including sexual abuse, while in the care of parent(s), legal guardian(s) or any other person who has the care of the child'

${ }^{79}$ State parties must ensure that 'No child shall be subjected to torture or other cruel, inhuman or degrading treatment or punishment'.

${ }^{80}$ Smith (1998), n 19 above.

${ }^{81}$ G. J. Boyle, J. S. Svoboda, C. P. Price and J. N. Turner, 'Circumcision of Healthy Boys: Criminal Assault?' (2000) 7 Journal of Law and Medicine 301-310.

82 J. S. Svoboda, 'Circumcision of male infants as a human rights violation' (2013) 39 Journal of Medical Ethics 469-474, 472

${ }^{83}$ Peter W. Adler, 'Is Circumcision Legal?' (2013) XVI: iii Richmond Journal of Law and the Public Interest 439-483.

${ }^{84}$ Adler, $\mathrm{n} 83$ above, 463-4.

85 Protects the right to life, security and development.

${ }^{86}$ Obliges states to protect children from sexual exploitation or abuse.

${ }^{87}$ Protects the child from exploitation prejudicial to their welfare.

${ }^{88}$ See P. Alston, 'The Best Interests Principle: Towards a Reconciliation of Culture and Human Rights' (1994) 8(1) International Journal of Law and the Family 1-25; S. Parker, 'The Best Interests of the Child - Principles and Problems' (1994) 8(1) International Journal of Law and the Family 26-41. 
context Art. 3(1) is seen to present a significant obstacle for those seeking to justify MGM, and for parents who decide that their boy child should in his best interests be circumcised. ${ }^{89}$ Related arguments about parental rights to freedom of religion are given similarly short thrift: those rights do not licence a parental decision which has 'nothing to do with their son's health' ${ }^{\prime 90}$ or, to put it differently, 'intruding into the child's bodily integrity in a sufficiently deep way cannot be justified by a pure liberty right such as freedom of religion' ${ }^{91}$ It has also been argued that parents are often not given adequate information about inherent risks upon which to provide fully informed consent, and that with informed consent a significant number would decide against authorising the procedure. ${ }^{92}$ Davis has pointed out that in fact parents cannot give consent, as it is not their autonomy which is at stake, but only legal permission. ${ }^{93}$ The very notion that parents have a legitimate right to consent to the circumcision of their boy children based on their own value systems has been called into question as 'The last remaining holdout for sovereignal freedom in the modern era' ${ }^{94}$ and an example of "dead dogma'. ${ }^{95}$

Beyond the UNCRC, children have the same right to bodily integrity as adults. ${ }^{96}$ In international law, provisions such as those found in the International Covenant on Civil and Political Rights (ICCPR) relating to bodily autonomy ${ }^{97}$ make this clear. ${ }^{98}$ Adler discerns a right of the child to be protected from the infringement of his rights by family, society or the state in Art. 5 of the ICCPR. ${ }^{99}$ Smith $^{100}$ and Svobola ${ }^{101}$ have identified other applicable rights, including the right to freedom from discrimination including 'The right to security of person and protection by the State against violence or bodily harm, whether inflicted by government officials or by any individual, group or institution'; ${ }^{102}$ the right to freedom from torture; ${ }^{103}$ as

\footnotetext{
${ }^{89}$ Adler (2013), n 83 above, 477.

${ }^{90}$ R. S. Van Howe, J.S. Svobola, J.G. Dwyer and C. P. Price, 'Involuntary Circumcision: The Legal Issues', (1999) 83 BJU Int'l 63-73, 68.

${ }^{91}$ R. Merkel and H. Putzke, 'After Cologne: male circumcision and the law. Parental right, religious liberty or criminal assault?' (2012) 39 Journal of Medical Ethics 444-449, 446.

92 J. S. Svoboda, R. S. Van Howe and J. G. Dwyer, 'Informed Consent for Neonatal Circumcision: An Ethical and Legal Conundrum' (2000) 17 Journal of Contemporary Health and Policy 61-133, 127.

http://scholarship.law.wm.edu/cgi/viewcontent.cgi?article=1166\&context=facpubs

${ }^{93}$ D. S. Davis, 'Ancient rites and new laws: how should we regulate religious circumcision of minors?' (2013)

39 Journal of Medical Ethics 458-458, 456.

${ }^{94}$ R. S. Van Howe, 'Infant circumcision: the last stand for the dead dogma of parental (sovereign) rights' (2013)

39 Journal of Medical Ethics 475-481, 475.

${ }^{95}$ Van Howe (2013), n 94 above, 475, borrows this term from J.S. Mill, for whom it was used 'to describe a belief that has gone unquestioned for so long and to such a degree that people have little idea why they accept it or why they continued to believe it'.

96 J. S. Svoboda, n 82 above, 469-474.

${ }^{97}$ For example, ICCPR, Arts 6 (right to life); 9 (right to liberty and security).

${ }^{98}$ Van Howe, Svobola, Dwyer and Price, n 81 above; Y. Hofvander, 'Circumcision in Boys: Time for Doctors to Reconsider' (2002) 38(2) World Hospitals and Health Services 15-17.

${ }^{99}$ Adler, n 83 above, 463. Art 5 protects against the destruction or unwarranted limitation of the rights of any person for any reason, and permits no restriction or derogation from that obligation on the grounds of law, conventions, regulations or custom.

100 Smith (1998), n 19 above.

${ }^{101}$ Svoboda (2013), n 82 above, 472.

102 Art. 5(b) International Convention on the Elimination of All Forms of Racial Discrimination. See Smith (1998).

${ }^{103}$ Art. 7 ICCPR; Art. 2 Convention Against Torture and Other Cruel, Inhuman or Degrading Treatment or Punishment.
} 
well as social and economic rights such as the right to health. ${ }^{104}$ Arguments have also been made in the context of the European Convention on Human Rights. Jane Fortin, for example, has argued that non-therapeutic MGM breaches the privacy right contained in Article 8(1) and cannot be justified under Article 8(2). ${ }^{105}$

There is also a set of less tangible - moral rather than legal - rights, the best known of which is probably the 'right to an open future' first proposed by Joel Feinberg. ${ }^{106}$ This refers to those rights which a child will have as an adult but cannot currently exercise. Examples include the rights to marry, to procreate, to sexual freedom, and the more general right to autonomy. Such rights are held on trust for the child during his or her minority or until capable of exercising them independently, which means that limitations can be placed on the present autonomy of the child to preserve the openness of her or his future. ${ }^{107}$ However, 'The converse does not apply: just because parents have the right to prevent their children from committing follies, such as a large tattoo or a permanent genital alteration, it does not mean that they have the right to impose such alterations themselves'. ${ }^{108}$ Rather, as the operation is painful, not without risk, and because it forecloses options unnecessarily, including options for sexual experience, 'when the later preferences of a child cannot be known, the safest course is, wherever possible, to keep the option open'. ${ }^{109}$

\subsection{Domestic law-based arguments}

MGM is seen to constitute an assault in terms of UK law. ${ }^{110}$ It certainly fits the basic requirements of such, and has been judicially recognised as involving actual bodily harm by the UK House of Lords. ${ }^{111}$ The onus is therefore on those who seek to justify the imposition of such harm to demonstrate the legality of that approach. In Finland in 2006, in the case of the boy ' $\mathrm{B}$ ', then four years old, it was held at first instance that his non-therapeutic circumcision for cultural and religious reasons, arranged by his mother and sole carer, constituted an assault. ${ }^{112}$ This decision was reversed on appeal, ${ }^{113}$ with that decision upheld by the Supreme Court in 2008, ${ }^{114}$ the Supreme Court finding that both Finnish national law and Articles 8 (privacy and family life) and 9 of the ECHR provided a legal basis for the circumcision.

\footnotetext{
${ }^{104}$ Article 12(1) of the International Covenant on Economic, Social and Cultural Rights provides for 'the right of everyone to the enjoyment of the highest attainable standard of physical and mental health' and Art. 12(2) places obligations on state parties to provide for the healthy development of the child.

105 J. Fortin, Children's Rights and the Developing Law (3rd edition, Cambridge University Press 2009), 395.

106 J. Feinberg, 'The child's right to an open future' in his Freedom and fulfilment: philosophical essays

(Princeton NJ: Princeton University Press, 1992).

${ }^{107}$ Feinberg, n 106 above, 89.

${ }^{108}$ R. J. L. Darby, 'The child's right to an open future: is the principle applicable to non-therapeutic circumcision?’ (2013) 39 Journal of Medical Ethics, 463-468, 464.

${ }^{109}$ Darby (2013), n 108 above, 467.

${ }^{110}$ Price (1997), n 76 above; Boyle et al (2000), n 81 above; Adler (2013), n 83 above, 461-462.

${ }^{111}$ Per Lord Templeman in $R$ v Brown (1994) 1 AC 212 at 231 E-F; see also Law Commission: Law Commission, Reform of Offences Against the Person: A Scoping Consultation Paper, Law Commission Consultation Paper No 217 (London: The Stationery Office, 2014), 2.56-2.57.

112 Tampereen käräjäoikeus, judgement 3073, 4 July 2006.

113 Turun hovioikeus, judgement No 497 (R 06/1990), 14 March 2007.

${ }^{114}$ Korkein oikeus, judgement KKO 2008: 93 (R2007/500), 17 October 2008. For discussion, see H. Askola, 'Cut-Off Point? Regulating Male Circumcision in Finland' (2011) 25(1) International Journal of Law, Policy and the Family 100-119.
} 
A court in Cologne, Germany ruled in May 2012 that non-therapeutic circumcision, performed for religious reasons on a four year old boy, amounted to grievous bodily harm, and could not be justified on the basis of parental consent because to undergo the procedure was not in the best interests of the boy. ${ }^{115}$ Subsequently, the German Federal Parliament introduced legislation ${ }^{116}$ to make it clear that MGM performed by a trained practitioner before the child reaches six months of age, and by a doctor after that time, is lawful. ${ }^{117}$ The new law was explained by Chancellor Merkel as being grounded in social inclusion and acceptance of religious diversity. ${ }^{118}$ The fact that the arguments in favour of recognising MGM as assault have so far been unsuccessful does not affect the normative argument that the law should recognise that an assault has happened. Although a claim of assault can sometimes be nullified by the presence of consent, the courts in these cases held that parental consent does not justify the assault or outweigh the interests of the boy in bodily integrity. As seen above, this argument is also made in the academic literature, with Adler adding the point that medical professionals have no right to conduct unnecessary surgical interventions on healthy boys,${ }^{119}$ described by Svobola as 'an ethically invalid form of medical violence. ${ }^{120}$

It is clear that MGM not based on a valid consent will constitute a battery in common law countries, and that the law of negligence applies to any MGM procedure, irrespective of the identity of the circumciser. ${ }^{121}$ It has been argued that MGM amounts to the tort of battery irrespective of whether or not there is consent in fact, because any such purported consent is invalid. This is because the rights of the parent(s) to act in the best interests of their child, or to exercise religious freedom, do not permit the infliction of unnecessary harm, ${ }^{122}$ and because the right to give consent on behalf of one's child applies only to medical treatment, whereas non-therapeutic MGM is not medical treatment. ${ }^{123}$

Adler, in a very thorough review of the position in American law, ${ }^{124}$ concluded that MGM breaches common law rights to personal security and liberty, ${ }^{125}$ and constitutional rights to equal protection, privacy, life, liberty, property and the pursuit of happiness, and freedom of religion. ${ }^{126}$ The Royal Dutch Medical Association (KNMG) has argued that MGM breaches rights to autonomy and physical integrity, protected by the Dutch Constitution. ${ }^{127}$ It has long

\footnotetext{
${ }^{115}$ Landgericht Koln, 7 May 2012, No. 151 Ns 169/11. This decision of the Regional Court overruled that made at first instance, in the Cologne district court, that parental consent authorised the procedure.

${ }^{116}$ Bundesgesetzblatt 2012, Teil I, Nr. 61, 2749. The new law is found as Art. $1631 \mathrm{~d}$ of the German civil code, in force from 1 January 2013.

${ }^{117}$ In the U.S.A. Congress in 2011 passed the Religious and Parental Defence Act, H.R. 2400, 112 ${ }^{\text {th }}$ Congress, prohibiting states from adopting any law to restrict the parental right to have their boy child circumcised.

118 'Circumcision remains lawful in Germany', http://www.dw.com/en/circumcision-remains-legal-ingermany/a-16399336 12 December 2012.

119 Adler, $\mathrm{n} 83$ above, 466-9.

${ }^{120}$ Svoboda (2013), n 82 above, 469.

${ }^{121}$ See D. J. Llewellyn, 'Legal Remedies for Penile Torts' (1995) 40 (Winter) The Compleat Mother, 16, for examples.

${ }^{122}$ Adler, n 83 above, 462-3, 473-478.

${ }^{123}$ Adler, $\mathrm{n} 83$ above, 461.

${ }^{124}$ Adler, $\mathrm{n} 83$ above.

125 Adler, $n 83$ above, 453-454.

${ }^{126}$ Adler, $\mathrm{n} 83$ above, 453-459.

${ }^{127}$ Koninklijke Nederlandsche Maatschappij tot bevordering der Geneeskunst (KNMG) KNMG Viewpoint Nontherapeutic circumcision of male minors (KNMG: Utrecht, 2010). The KNMG does not call for an outright legal prohibition of MGM, however, on the basis that that would simply drive the practice underground and increase its attendant health risks https://www.knmg.nl/circumcision/, 5, 16.
} 
been argued that 'Since circumcision is medically unwarranted mutilation and disfigurement, it would appear to be a clear case of child abuse', ${ }^{128}$ and such arguments are still routinely encountered in the literature. ${ }^{129}$

Although, as seen above, various courts applying various laws in various jurisdictions have held that MGM is lawful, the legal literature to support this view is notably thinner on the ground than articles hostile to the practice. Mark Swatek-Evenstein notes that the case for the legality of the practice in international law has not been positively made, and that 'In the absence of specific provisions, any opinions on the legality of the practice have to be derived from the wider framework of the (potentially) applicable law, e.g. the United Nations Convention on the Rights of the Child, or guarantees of religious freedom under the International Covenant on Civil and Political Rights (Article 18) and Article 18 of the Universal Declaration of Human Rights insofar as it may be a statement of customary international law'. ${ }^{130}$ Despite Swatek-Evenstein's claim, it is possible to find examples of arguments making the legal case for circumcision. Freeman for example has argued that 'To deny a Jewish or Muslim child a circumcision removes from him the ability fully to participate in the religious life of his community' and therefore 'ritual circumcision is in their best interests' and an expression of various rights such as the right to freedom of religion found in Art. 9 UNCRC. ${ }^{131}$ Mazor grounds his argument for the permissibility of circumcision in the parental right to make decisions in the best interests of their sons. ${ }^{132}$ Nonetheless it is striking that the sustained and widespread legal academic criticism described above has not been engaged with by key international actors. In the next section of the paper, I suggest that one reason why this may be the case is that the international actors discussed above operate with simplistic models of gender and sexuality, that render them unable to identify harm that occurs outside a narrow grid of reference for understanding gender- and sexuality-based breaches of the rights of the child.

\section{Gender and sexuality}

What is most striking about the theories of gender and sexuality that are relied upon by the international actors discussed above to identify breaches of the rights of the child and develop responses is their simple binary nature. As detailed in section two above, it is the view of WHO that FGM reflects 'deep-rooted gender inequality that assigns women an inferior position in societies, and is unambiguously linked to a reduction in women's sexual desire and an irreversible loss of capability for a type of sexual functioning that many women value highly'. ${ }^{133}$ In this view, one's gender is a source of power for men, and of oppression for women. What is empowered or oppressed, at both a cultural and an individual level, is

\footnotetext{
${ }^{128}$ W. E. Bridgman, 'Circumcision as Child Abuse: The Legal and Constitutional Issues' (1985) 23(3) University of Louisville Journal of Family Law 337 http://www.cirp.org/library/legal/brigman/.

${ }^{129}$ Adler, n 83 above, 459.

${ }^{130}$ Swatek-Evenstein (2013), n 73 above, 43.

${ }^{131}$ M.D.A. Freeman, ‘A child's right to circumcision' (1999) 83, Suppl. 1 BJU International 74-78, 77.

132 J. Mazor, 'The child's interest and the case for the permissibility of male infant circumcision' (2013) 39

Journal of Medical Ethics 421-428; for other recent examples, see A. J. Jacobs and K. S. Arora, 'Ritual Infant Circumcision and Human Rights' (2015) 15(2) American Journal of Bioethics 30-39; B. E. Rivin, D. S.

Diekema, A. C. Mastroianni, J. N. Krieger, J. D. Klausner and B. J. Morris, 'Critical Evaluation of Adler's Challenge to the CDC's Male Circumcision Recommendations' (2016) 24 International Journal of Children's Rights 265-303, especially at 282-289.

${ }^{133}$ WHO and UNAIDS, (2007), n 6 above, 27.
} 
sexuality, although empowerment or oppression through one's sexuality is also the gateway into a broader culture of systemic gender inequality.

This is a view very reminiscent of the 'radical' feminist position articulated by writers such as Shulamith Firestone ${ }^{134}$ (and applied to 'female circumcision' thereby converting it into 'FGM' ${ }^{135}$ ) in the 1970s, and further developed in the 1980s by authors like Catherine Mackinnon; in which gender is understood as a dialectic, unequal, relationship of opposites. Mackinnon's contribution was in part to problematicise biological essentialist notions of gender. She argued that 'gender is a social system that divides power. It is therefore a political system... the relation between women and men is political'. ${ }^{136}$ From this point of view, 'gender' is the mechanism which encultures and politicises biological differences between men and women. Sex as difference becomes gender as domination, and the two terms - sex and gender - are virtually interchangeable; or at least, the difference between them is obfuscated. The documents under analysis here tend to use the terms in this vague way. ${ }^{137}$

The work of Mackinnon and others has been massively influential, and rightly so, because it exposed an important truth about gender and power. But it was soon criticised by those who took a more nuanced approach, arguing not that gender was the mechanism by which culture suppresses and substitutes the truth of women existing externally to or before patriarchal power, but rather that culture and power produced that truth, as both (insofar as these things are distinct) psychic and material reality. Judith Butler, for example, influentially argued that gender was not a modification of pre-existing sex differences. Rather, for Butler, "The category "sex" is, from the start, normative... "sex" not only functions as a norm, but is part of a regulatory practice that produces the bodies it governs, that is, whose regulatory force is made clear as a kind of productive power, the power to produce - demarcate, circulate, differentiate - the bodies it controls'. ${ }^{138}$ In this view, there is no (accessible) space external to culture, no pre-existing domain of the biological, or the natural, which culture then modifies. Rather, the construction of the biological as such is in fact a cultural or social artefact. As Butler explains:

The social construction of the natural presupposes the cancellation of the natural by the social. Insofar as it relies on this construal, the sex/gender distinction founders along parallel lines; if gender is the social significance that sex assumes within a given culture, then what, if anything, is left of "sex" once it has assumed its social character as "gender"....sex does not accrue social meanings as additive properties but, rather, is replaced by the social meanings it takes on - "gender" emerges, not as a term in a continued relationship of opposition to sex, but as the term which absorbs and displaces "sex". ${ }^{139}$

Moreover, the social meanings which have been articulated and infused into the materiality, the bodies, of individual people have not been random. The normative injunctions and regulatory practices which have developed are in the service of the consolidation of the

\footnotetext{
${ }^{134}$ S. Firestone (1970) The Dialectic of Sex: The Case for Feminist Revolution, William Morrow and Company: New York.

${ }^{135}$ F. P. Hosken, The Hosken Report: Genital and Sexual Mutilation of Females (Women's International Network News: Lexington, MA, 1978, Fourth Revised Edition 1994). WHO did not officially adopt the term until its 1990 conference at Addis Ababa.

${ }^{136}$ C.A. MacKinnon, Towards a Feminist Theory of the State (Cambridge, MA: Harvard UP, 1989), 160-161.

${ }^{137}$ See for example CEDAW and CRC (2014), n 60 above, para. 6, 7, 15, 17; WHO et al (2008), n 1 above, 5, 10.

${ }^{138}$ J. Butler, Bodies That Matter: On The Discursive Limits of "Sex” (Abingdon: Routledge, 1993), 1.

${ }^{139}$ Butler, above n 138, 5 .
} 
heterosexual imperative'. ${ }^{140}$ This does not entail the absence of agency, but individual agency inevitably functions in some relation to this context. Gender, in Butler's terminology, is 'performative': ${ }^{141}$ being/doing one's gender is a matter of conforming (or not) to cultural expectations in both psychological and 'material' (i.e. bodily) terms.

Butler's ideas certainly seem to resonate with common understandings of FGM: for a girl child in cultures where there is a norm and expectation of genital modification, being a girl and later a woman entails both compliance with ways of thought and action compatible with one's gender as defined by that cultural context but also entails bodily modification - the culturally-required re-working of one's biological materiality. Those who do not comply with these expectations are seen as deficient examples of their gender, somehow both belonging and not belonging to it. We can expect psychological trauma in consequence. To quote Butler again, the consequence is that individuals who do not or cannot comply with cultural expectations are "living under the sign of the "unlivable", required to circumscribe the domain of the subject'. ${ }^{142}$ Such individuals are in a sense necessary to the heterosexual imperative, since they can be made an example of, identified as the 'other', used as a device to represent the 'abnormal' and hence bring the substance and content of the normative into sharp relief.

This perspective raises a host of disparate issues, far more than can be explored here. For example, can a valid consent ever be given in a cultural context which is heavily loaded with normative expectations? Conversely, can it be ethical to deny the possibility of cultural conformity to either girls or boys if the alternative is to live as an outcast, to live an 'unliveable' life? It is certainly the case that in the discourse around FGM, the voices of women who have undergone FGM and defend the practice and their right to choose it, are marginalised, ${ }^{143}$ and assessments of its impact of sexual functioning and sexuality at odds with the orthodoxies of that discourse are not often heard. ${ }^{144}$ In the present context, however, there are two issues which I wish to highlight. The first is the understanding of the body and its relation to models of gender and sexuality which this approach implies. Butler argues that 'it is through the body that gender and sexuality become exposed to others, implicated in social processes, inscribed by cultural norms, and apprehended in their social meaning'. ${ }^{145}$ The body as a cultural artefact is always already, inescapably, gendered, and therefore normative, and any individual body is more or less proximate to the cultural prescriptions of its particular context. Diverse vectors of normality - body shape, age, colour, behaviour, attitude and sexuality for example - intersect it, categorise it, constitute it as a lived reality. Secondly, although one gains no clue to this from reading any WHO, UN or CRC documents, these imperatives of gender and sexuality envelop males as much as females. The 'unliveable

\footnotetext{
140 Butler, above, n 138, 2.

${ }^{141}$ J. Butler, Gender Trouble: Feminism and the Subversion of Identity (Abingdon: Routledge, 1990).

142 Butler, n 138 above, 3.

${ }^{143}$ See for example R. M. Abusharaf, 'Revisiting Feminist Discourses on Infibulation: Responses from Sudanese Feminists' and F. Ahmadu, 'Rites and Wrongs: An Insider/Outsider Reflects on Power and Excision' in Female 'Circumcision' in Africa: Culture, Controversy and Change, B. Shell-Duncan and Y. Hernlund (eds) (Boulder, Co: Lynne Rienner, 2000); R. A. Shweder (2013) 'The goose and the gander: the genital wars' 3(2) Global Discourse, 348-366.

${ }^{144}$ Hastings Centre Report (2012) Seven Things to Know About Female Genital Surgeries in Africa (The Public Policy Advisory Network on Female Genital Surgeries in Africa, 2012), 22: 'a high percentage of women who have had genital surgery have rich sexual lives, including desire, arousal, orgasm and satisfaction, and their frequency of sexual activity is not reduced'

145 J. Butler, Undoing Gender (Abingdon: Routledge, 2004), 20.
} 
life' haunts masculinity as much as femininity, since both function as a norm. It is therefore necessary to ask how MGM is implicated in this normative regulatory system.

This may all seem to be getting hopelessly abstract, but the point can be expressed simply. To be, for example, a gay man living in a hetero-orthodox cultural context, ${ }^{146}$ or, more pertinently for present purposes, to be a boy living in a world of adult authority - to be a son living in the house of his father - is to experience and be required to negotiate patriarchal power, whether that means conforming to or contesting the norms which that culture and its agents seek to impose. It is true that MGM is not located within the same history of gender inequality and male violence towards women as is FGM, but from a children's rights point of view, it is located within a parallel and overlapping history of age inequality and adult control of/violence towards children. Nura Taefi has suggested, in seeking to demonstrate the particular vulnerabilities inherent in the position of the girl child, that 'the experience of adulthood defines what it means to be a woman and the experience of being male defines what it is to be a child. Disenfranchised and disregarded, girls are most often excluded from the decisions that affect them'. ${ }^{147}$ Insofar as this might be seen as reproducing the assumption that boys cannot be the victims of gender-based oppression in a patriarchal context, Taefi risks making the same categorical error as Mackinnon. But Taefi's model, of 'intersectionality', derived from the influential work of Crenshaw ${ }^{148}$ and McCall, ${ }^{149}$ can in fact be fairly readily modified to fit the case of boys. Such a model would ask how boys are excluded from decisions which affect them by the realities that the experience of adulthood defines what it means to be a man and the experience of being male defines what it is to be a child. We might expect, given the broader patriarchal context, that the triggers and intensities which impact on boyhood would differ in shape and scope from those which impact on girlhood. But it is not a case of totting up the number of vectors of discrimination, so as to be able to argue that girls are more disenfranchised and disregarded than boys. Rather, the point is that the gender- and age-specific cultural features of boyhood as they impact on the rights of the boy child should be given the same importance as is the case for girls.

\section{Circumcision and sexuality}

One crucial difference between FGM and MGM in WHO discourse, and which helps explain the virtual absence of any consideration of MGM by the CRC, is that the former is regarded as the control or theft of the sexuality of girls and the women they will become, whereas MGM is not seen to have any implications for the sexuality of boys and the men they will become. The WHO view seems to be that the equivalent of clitoridectomy would be removal of the penis rather than circumcision ${ }^{150}$ - the organ itself rather than its housing - and there is

\footnotetext{
${ }^{146}$ International Lesbian, Gay, Bisexual, Trans and Intersex Association: A. Carroll, State-Sponsored Homophobia a World Survey of Sexual orientation laws: Criminalisation, protection and recognition (Geneva; ILGA, 11th edition, May 2016).

${ }^{147}$ N. Taefi, 'The Synthesis of Age and Gender: Intersectionality, International Human Rights Law and the Marginalisation of the Girl-Child', (2009) 17 International Journal of Children's Rights, 345-376, 348.

${ }^{148}$ K. Crenshaw, 'Mapping the Margins: Intersectionality, Identity Politics, and Violence Against Women of Color' (1991) 43(6) Stanford Law Review, 1241-1299.

${ }^{149}$ L. McCall, 'The Complexity of Intersectionality' (2005) 30(3) Signs: Journal of Women in Culture and Society, 1771-1800.

${ }^{150}$ WHO, UNICEF and UNFPA (1997), n 23 above, 8: 'almost all types of female genital mutilation involve the removal of part or all of the clitoris, which is the main sexual organ, equivalent in its anatomy and physiology to the male penis'. Bell (2005) cites academic authority making the same claim.
} 
seen to be no current practice equivalent to the infibulation of girls. ${ }^{151}$ As Bell notes, "These male and female genital operations are not merely seen to differ in degree, they are seen to differ in kind' ${ }^{152}$ There are two aspects to this. The first is concerned with the level of invasiveness and the depth of harm - including the 'irreversible loss of capability for a type of sexual functioning that many women value highly', which entails the loss of libido or sexuality as well as the loss of physical capacity. WHO, citing Berg et al, ${ }^{153}$ state that

Sexual problems are also more common among women who have undergone FGM. They are 1.5 times more likely to experience pain during sexual intercourse, have significantly less sexual satisfaction and are twice as likely to report a lack of sexual desire. $^{154}$

This difference in kind is also, as seen above, understood by WHO in terms of the cultural context of 'deep-rooted gender inequality' and the 'inferior position' of women in patriarchal societies $^{155}$ (although there is no serious attempt to grapple with the full implications of a culturally sensitive model of gender and sexuality). ${ }^{156}$ In sharp contrast, all that WHO has to say about the relevance of these issues to MGM is that 'The impact of circumcision on sexual function has not been systematically reviewed, and remains unclear due to substantial biases in many studies', ${ }^{157}$ and that 'there is little evidence' to support claims that circumcision reduces male sexual function. ${ }^{158}$ Nor is there any attempt to factor in broader questions of sexuality or to position MGM in any sort of gendered or gendering context.

Rather, WHO adopts a narrow, mechanistic view of male sexuality: what is meant by 'sexual function' seems to be no more or less than that the ability of a boy, when sexually active in later life, to achieve and maintain an erection and to ejaculate, is not removed by circumcision, ${ }^{159}$ or only very rarely, and usually only then because of deficiencies in the way the procedure was carried out. That is, unlike the way in which FGM is conceptualised, as constituting some sort of meeting point for female sexual function, female sexuality, and femininity as gender, the discursive strategy used by WHO in respect of MGM is to uncouple sexual functioning from sexuality, and sexuality from gender. The notion of male sexuality beyond the mechanistic requirements of the heterosexual act of procreation seems to be a possibility which does not occur to this key international actor.

\footnotetext{
${ }^{151}$ M. Nussbaum, Sex and Social Justice (New York: OUP, 1999) 119, suggests that 'The male equivalent of infibulation would be "removal of the entire penis its roots of soft tissue, and part of the scrotal skin", citing N. Toubia, Female genital mutilation: a call for global action (Mexico City: Women, Ink, 2 ${ }^{\text {nd }}$ ed, 1995), 9. Toubia defines male circumcision as 'nonmutilating'.

152 Bell (2005), n 13 above, 131.

${ }^{153}$ R. C. Berg, E. Denison and A. Fretheim, Psychological, Social and Sexual Consequences of Female Genital Mutilation/Cutting (FGM/C): A Systematic Review of Quantitative Studies (Oslo: Norwegian Knowledge Centre for the Health Services, 2010); R. C. Berg and E. Denison 'Does Female Genital Mutilation/Cutting (FGM/C) Affect Women's Sexual Functioning? A Systematic Review of the Sexual Consequences of FGM/C' (2012) 9(1) Sexuality Research and Social Policy, 41-56.

${ }^{154}$ WHO, Understanding and addressing violence against women Female genital mutilation (WHO: Geneva, 2012), 3, http://apps.who.int/iris/bitstream/10665/77428/1/WHO_RHR_12.41_eng.pdf

${ }^{155}$ WHO and UNAIDS (2007), n 6 above, 27.

${ }^{156}$ S. Johnsdotter, 'Discourses on sexual pleasure after genital modifications: the fallacy of genital determinism (a response to J. Steven Svoboda)' (2013) 3(2) Global Discourse, 256-265.

${ }^{157}$ WHO and UNAIDS, (2007), n 6 above, 16.

${ }^{158}$ WHO and UNAIDS, (2007), n 6 above, 16, citing studies references 4, 43, 146-148.

${ }^{159}$ As Bell (2005), n 13 above, amongst others has shown, such views are commonly encountered in both academic and popular discourses and understandings of MGM.
} 
There is no acknowledgement by WHO of the way in which male sexuality is normatively shaped by cultural forces, or of the fact that MGM in and of itself functions as a cultural message of one sort or another about male sexuality, most often justifying the removal of flesh 'coded as excessive, redundant, polluted or feminine'. ${ }^{160}$ The gendered quality of these constructions and practices is obscured by apparently gender-neutral, macro-level, discourses around health and hygiene, religion and faith. This sharp distinction between discourses around FGM and MGM does not chime with the experiences or understandings of many. Caldwell, Orubuloye and Caldwell ${ }^{161}$ found in studies carried out in three areas of south west Nigeria that female and male circumcision were conceptualised as interrelated practices, both designed to achieve a variety of psycho-social functions in terms of gender and cultural identity. ${ }^{162}$ In the Sudan, FGM is seen to remove the 'masculine' clitoris and labia, and MGM the 'feminine' foreskin, rendering initiates of each ritual ready for adulthood and marriage as full members of their respective sex. ${ }^{163}$ Indeed, WHO, in giving very brief mention to the rite of skin-stripping, explains that it is 'used to prove bravery, and therefore marriage suitability, among various ethnic groups', ${ }^{164}$ and that, in cultural settings where circumcision is a traditional practice 'In the majority of these cultures, circumcision is an integral part of a rite of passage to manhood, although originally it may have been a test of bravery and endurance. Circumcision is also associated with factors such as masculinity, social cohesion with boys of the same age who become circumcised at the same time, self-identity and spirituality'. ${ }^{165}$ Such ideas may be less to the fore in the secular, health-based, circumcision 'industry' in the USA and other 'developed' nations, inheritors of a health-based history of MGM and the pathologisation of the foreskin, rather than one tied to cultural discourses around individual and collective identity, but here too there is ample evidence that MGM is inextricably linked to normative images of masculinity and notions of inclusivity/exclusivity. ${ }^{166}$

The pathologisation of the foreskin in the latter decades of the $19^{\text {th }}$ century was always seen as a mechanism for the control or regulation of male sexuality, ${ }^{167}$ just as female circumcision was seen to have the same function. ${ }^{168}$ Some, who disagree with the claim that there is little

${ }^{160}$ M. Fox and M. Thomson, 'Foreskin is a Feminist Issue' (2009) 24(60) Australian Feminist Studies, 195-210, 196; J. Zoske 'Male Circumcision: A Gender Perspective' (1998) 6(2) Journal of Men's Studies, 189-208; D. M. Harrison, 'Rethinking Circumcision and Sexuality in the United States' (2002) 5(3) Sexualities, 300-316, 303, citing M. Anchell Sex and Sanity (New York: Macmillan, 1971), 135: 'foreskin is an anatomical remnant from a previous stage of evolution when it served a purpose. Today it is useless and may cause physical problems'.

${ }^{161}$ J.C. Caldwell, I.O. Orubuloye and P. Caldwell, 'Male and Female Circumcision in Africa from A Regional to a Specific Nigerian Examination' (1997) 44(8) Soc. Sci. Med., 1181-1193.

${ }^{162}$ See also J. Kenyatta, Facing Mount Kenya: The Tribal Life of the Gikuyu (London: Secker and Warburg, 1938), 134; C.O. Knudsen, The Falling Dawadawa Tree: Female Circumcision in Developing Ghana (Hojbjerg, Denmark: Intervention Press, 1994), 58; R.A Myers, F.I. Omorodion, A.E. Isenalumhe and G.I. A

Kenzua, 'Circumcision: its nature and practice' (1985) 21 Social Science and Medicine 581-588, 587.

163 J. Boddy, 'Gender crusades: The female circumcision controversy in cultural Perspective' in Transcultural bodies: Female genital cutting in global context, edited by Y. Hernlund and B. Shell-Duncan. (New Brunswick, NJ: Rutgers University Press, 2007), 60, cited by Fox and Thomson (2009), n 159 above, 199-200.

${ }^{164}$ WHO and UNAIDS, (2007), n 6 above, 21.

${ }^{165}$ WHO and UNAIDS, (2007), n 6 above, 4, footnotes omitted.

${ }^{166}$ See for example Harisson (2002), n 160 above, 304; D.L. Gollaher, 'From Ritual to Science: The Medical Transformation of Circumcision in America' (1994) 5 Journal of Medical History, 5-36; Kalcher and Swan, $\mathrm{n}$ 34 above.

${ }^{167}$ See for example Robert Darby, A Surgical Temptation: The Demonization of the Foreskin and the Rise of Circumcision in Britain (Chicago: Chicago University Press, 2005); K. E. Paige, 'The Ritual of Circumcision' (1978) Human Nature 40-48.

${ }^{168}$ S. W Rodriguez, 'Rethinking the history of female circumcision and clitoridectomy: American medicine and female sexuality in the late nineteenth century' 63(3) J Hist Med Allied Sci., 323-47. For contemporary accounts see for example D. A. Zambaco, 'Masturbation and Psychological Problems in Two Little Girls', first published 
evidence that circumcision harms sexual function, see contemporary advocates as disingenuous, turning a calculated blind eye to 'the physical and functional facts - as well as the abundant testimony from men who insist that they have been harmed by circumcision' whereas 'Their nineteenth century predecessors were more consistent and more honest, admitting that they wanted to destroy the foreskin precisely because they knew very well that it would make a (diminishing) difference to sexual experience'. ${ }^{169}$ Circumcision as a mechanism to reduce sexual drive is still frequently used as part of the explanation for the practice in various cultural contexts. ${ }^{170}$

In point of fact, conclusive scientific, as opposed to anecdotal, evidence that either MGM or FGM of whatever type has a detrimental effect on sexual functioning is not currently available. The meta-analysis conducted by Berg and colleagues, relied on by WHO, found that only two of fifteen studies of FGM analysed were of high quality in terms of methodology and the robustness of their findings, and ten of the studies were of poor quality in those terms. ${ }^{171}$ In a sense, however, the whole debate around sexual functioning is inappropriately framed. Whether girl or boy, it seems unarguable that the removal of healthy tissue laden with nerve-endings must necessarily impact on the sensory experience of sexual behaviour in adulthood, whether or not seen as beneficial, detrimental, or just different. And just as for girls it seems unarguable that, as WHO puts it, FGM, at least of types 1, 2 or 3 results in a 'loss of capability for a type of sexual functioning', so too for boys the removal of the foreskin results in the loss of capability for certain types of sexual functioning. Harisson gives the example of 'docking', a sexual activity whereby one male extends his foreskin to envelop the head of the penis of his partner. ${ }^{172}$ As he notes, this is a practice outside the normative heterosexual frame of reference for acceptable sexual activity, but the foreskin has erogenous capacities in all sexual contexts. The point is that this is not a question of sexual functioning, narrowly understood in terms of the possibility of engaging in heterosexual intercourse, but is rather a matter of sexuality and sexual possibility. When the way in which 'sexual functioning' is understood is broadened to include practices of sexuality beyond the procreative, it seems unarguable that MGM functions as a loss. What is peculiar about WHO (non-)discourse around MGM is that on the one hand it acknowledges that circumcision raises issues of sexuality and gender identity, but on the other hand - and in sharp contrast from the way in which FGM is presented and framed in its discourse - it is silent as to the specific dynamics which are at play.

Logic dictates that, if FGM is performed and experienced against the broader patriarchal context then so too is MGM. Circumcision is more than a physical act of cutting. It engenders and genders the body, implicates the body in a myriad of competing power dynamics, puts the notion of 'sexual function' in a cultural context, maps and circumscribes it in normative terms. It also valorises the penis over other body parts. There is often little clue to be had on

as 'Onanisme avec troubles nerveux chez deux petit filles' (1882) 2 L'Enciphale, 88-95 and 160-174; G. Braun, 'The Amputation of the Clitoris and Labia Minora: A Contribution to the Treatment of Vaginismus', first published as 'Die Amputation der Clitoris und Nymphen, ein Beitrag des Vaginismus' (1865) 15 Weiner medizinische Wochenschrift 1325-28 and 1341-44, both reprinted in J. M. Masson (ed) A Dark Science: Women, Sexuality and Psychology in the Nineteenth Century (New York: The Noonday Press, 1986).

${ }^{169}$ Van Howe (2013), n 94 above, 479.

${ }^{170}$ S. K. Hellstein, 'Rationalising circumcision: From tradition to fashion, from public health to individual freedom - Critical notes on cultural persistence of the practice of genital mutilations' (2004) 30(3) Journal of Medical Ethics 248-53; T. Kepe, "'Secrets” that kill: Crisis, custodianship and responsibility in ritual male circumcision in the Eastern Cape Province, South Africa' (2010) 70 Social Science \& Medicine, 729-735.

171 Johnsdotter (2013), n 156 above.

${ }^{172}$ Harisson (2002), n 160 above, 310-311. 
reading the medical literature that the penis has any particular cultural significance by comparison with other body parts. But the penis, as the phallus, always gestures beyond itself, its materiality and its utility. The penis, as the phallus, symbolises male social, economic, cultural and political supremacy ${ }^{173}$ and, for some, marks the limits of reality and of what may be thought. ${ }^{174}$ The penis metaphorises masculinity in general and specific masculinities. From this point of view, MGM is the mechanism for the imposition of dominant masculinities and masculine sexualities onto the boy child. This occurs both at the micro-level - the penis as an aesthetic representation of 'manhood'175 and at a macro-level where the ideal of manhood which the circumcisor seeks to realise needs 'to be understood in terms of how we imagine or corporealise the body politic'. ${ }^{176}$

Logic would also seem to suggest that a practice which the dominant patriarchal culture imposes on its own privileged members would be done in the service of enhancing those privileges. That is, MGM should have a socio-political utility for patriarchy. In one sense, the very gender-specificity of MGM operates in this way, as an exclusionary mechanism. For example, the Jewish religious discourse around MGM, in which the circumscribed penis of the boy child is both a communication, a covenant, with divinity and a badge of belonging, takes for granted the patriarchal reality that the father is the head of the household and so it is he, not his wife, who engages in dialogue with the divine. Lacking a penis, woman cannot enter into the covenant as a principle party. In short, the coherence of this discourse justifying MGM is dependent, first, on woman as other.

Practiced within a patriarchal culture or sub-culture, circumcision valorises, articulates, and perpetuates that culture and its necessary qualities and inequalities. The boy child is claimed and marked by circumcision, thereby brought or confirmed within the jurisdiction of a regulatory system of masculinity which expects the exhibition and enhancement of qualities deemed to be masculine. The boy child, like the girl child, is a 'prisoner of ritual'. ${ }^{177}$ Circumcision of the boy child is performativity by proxy, an appropriation of future autonomy. Circumcision divides masculinities: at times it has been a mark of shame or inferiority, at other times a manifestation of superiority. ${ }^{178} \mathrm{Kepe}$, discussing the politics of circumcision in Eastern Cape Province, cites media reports that circumcision is denied to homosexual boys. ${ }^{179}$ Generally, as Boon has observed, "circumcision involves signs separating an "us" from a "them" entangled in various discourses of identity and distancing' ${ }^{180}$ Circumcision in other words functions as a border, a mark of inclusion but also of exclusion, implicated in a normative politics of masculinity which excludes both the feminine and inappropriate masculinities. It is for this reason that some have argued that

\footnotetext{
${ }^{173}$ M. Fox and M. Thomson 'Sexing the cherry: fixing masculinity', in Queer(ing) Somatechnics: Critical Engagements with Bodily (Trans) Formations, N. Sullivan and S. Murray (eds) (Farnham: Ashgate, 2009a), 107-126.

174 See J. Lacan, 'The Signification of the Phallus' in Ecrits: The First Complete Edition in English (London: W. W. Norton \& Company, 2007).

175 A.J. Jacobs and K. S. Arora, 'Ritual Infant Male Circumcision and Human Rights' (2015) 15(2) The

American Journal of Bioethics, 30-39, 32.

${ }^{176}$ Fox and Thomson, (2009a), note 172 above, 117.

${ }^{177}$ H. Lightfoot-Klein, Prisoners of Ritual: An Odyssey into Female Genital Circumcision in Africa (New York: Haworth Press, 1989).

${ }^{178}$ Kalcher and Swan (2010), n 34 above, 18-20 provide disparate examples.

${ }^{179}$ Kepe (2010), n 170 above, 735.

180 J. A. Boon, 'Circumscribing Circumcision/Uncircumcision: An Essay Amidst the History of Difficult Description', in S. Schwartz (ed) Implicit Understandings (New York: Cambridge University Press, 1994), 556$85,556$.
} 
MGM is a feminist issue, to be understood as a producer and expression of patriarchal power relations. ${ }^{181}$ Over and above the inherent harm and breach of bodily autonomy which characterises MGM, for this reason, too, it is a children's rights issue.

\section{Concluding Comments}

The campaign to eradicate FGM has for some while been one of the most highly profiled aspects of international efforts to protect and enhance the rights of the child. Recent data published by UNICEF shows that more women and girls - now said to be around 200 million - have been subject to FGM than was previously thought, and without greater efforts merely to keep abreast of population increase, the numbers will continue to rise. ${ }^{182}$ As such, further intensification of efforts to eradicate the practice can be confidently expected. Meanwhile, the various practices of the circumcision of boys continue unchallenged, and WHO and the UN bodies are busy orchestrating the programme for the mass circumcision of millions of young men and boys across countries in eastern and southern Africa as part of their strategy to reduce the incidence of HIV/AIDS. Taefi has argued that the issue of harmful traditional practices is the one area where the rights of the girl child are not marginalised by the Convention on the Rights of the Child and other international law. ${ }^{183}$ Ironically, however, the central positioning of the rights of girls in debate and policy around traditional practices has resulted in the marginalisation of the boy child and his rights in this area.

According to the key international actors in the field, the difference in approach is explicable in terms of the radical distinction between the two sets of practices. Yet as I have attempted to show in this article, this claim cannot be maintained. Although some argue for the continuation of the circumcision of boys, but subject to age limits, the requirement to use anaesthetic, and the outlawing of various ritual forms of circumcision, ${ }^{184}$ others more critical of the current approach of international actors to MGM have suggested ways in which the situation could be more fundamentally reformed. The common feature of these arguments is that they advocate some form of paradigm shift. Van den Brink and Tigchellaar, for example, argue that human rights principles should be applied 'in a more universalist and less gender and culture biased way' to FGM and MGM. ${ }^{185}$ Van Howe suggests that the proper application of a human rights perspective would mean an end to parental rights, to be replaced with 'a responsibility to protect and promote the basic human rights of their child'. ${ }^{186}$ Fox and Thomson ${ }^{187}$ have argued for the replacement of the health paradigm around MGM by a social justice paradigm, in which health is demoted, so as to be only one relevant factor, ${ }^{188}$ and 'entails the application of human rights to public health and health policy' ${ }^{189}$

\footnotetext{
${ }^{181}$ Fox and Thomson, (2009) n 160 above, 195-210; R. Steinfeld and T. Lyssarides 'Male Circumcision is a Feminist Issue too' (2015) Hysteria, $28^{\text {th }}$ January 2015, http://www.hystericalfeminisms.com/malecircumcision-is-a-feminist-issue-too/; C. G. Wilson, 'Male genital mutilation: an adaption to sexual conflict' (2008) 29 Evolution and Sexual Behaviour, 149-164.

182 UNICEF (2016) Female Genital Mutilation/Cutting: A Global Concern, http://www.unicef.org/media/files/FGMC 2016 brochure final_UNICEF_SPREAD(2).pdf.

${ }^{183}$ N. Taefi (2009), n 147 above, 356-359.

${ }^{184}$ B.Y. Hanoch, 'Circumcision: What should be done?' (2013) 39 J Med Ethics, 459-462.

185 Van den Brink and Tigchellaar (2012), n 10 above, 445.

186 Van Howe (2013), n 94 above, 480.

${ }^{187}$ Fox and Thomson (2012), n 54 above, 255-281.

${ }^{188}$ In this paradigm, or frame, health sits alongside personal security, reasoning, respect, attachment and selfdetermination: Fox and Thomson (2012), n 54 above, 268.

${ }^{189}$ Fox and Thomson (2012), n 54 above, 268.
} 
Although the authors develop their argument with specific reference to the campaign in southern and eastern Africa to encourage male circumcision as a way to reduce the spread of HIV/AIDS, it has a more general application and resonance. Earp has argued for a paradigm based on autonomy and informed consent, rather than gender and harm, to apply equally to girls and boys. ${ }^{190}$

Yet, although there is clearly much merit to these suggestions, my concern is that unless underlying theories of gender and sexuality are consciously re-worked by international actors, any attempts to reorient the policy paradigms around FGM and MGM will be stymied. Without the rethinking of these models of gender and sexuality, and their dynamic interaction with and as power, so that MGM can be recognised as being every bit as much the product of patriarchy as FGM, arguments about international policy and practice are unable to get off the ground. This is because these models cannot recognise or compute MGM as harm in the first place. There may be a certain wilfulness about this inability to compute. Challenging MGM is a much more delicate and fraught enterprise than challenging FGM in political terms, involving a challenge to the belief systems of two major world religions, risking accusation of anti-Semitic or anti-Islamic intent, ${ }^{191}$ and to the medico-cultural practices of powerful developed nations such as the United States. I am not in a position to judge the reality of such concerns as they impact on actors such as WHO, UN human rights bodies and the CRC. Some may feel that these potentially deep and turbulent waters are best avoided. But that has not been my concern here. I have, rather, sought to uncover the deficiencies in the theories of gender and sexuality which those actors deploy, and have suggested that those deficiencies obscure an important field of harm to boy children in breach of their rights.

190 Earp (2015), n 15 above, 89-104.

${ }^{191}$ D. P. Goldman, 'The Sacred Rite of Circumcision' (2012) Tablet, August 92012,

http://www.tabletmag.com/jewish-life-and-religion/108801/sacred-rite-of-circumcision. 